\title{
Phosphorus Source Affects Phosphorus Leaching and Growth of Containerized Spirea
}

\author{
Arleen Godoy ${ }^{1}$ and Janet C. Cole ${ }^{2}$ \\ Department of Horticulture and Landscape Architecture, Oklahoma State \\ University, Stillwater, OK 74078-6027
}

Additional index words. cuttings, fertilizer, leachate, nursery production, Spiraea nipponica, substrate

\begin{abstract}
Commercially propagated 'Halward's Silver' spirea (Spiraea nipponica Maxim.) bareroot cuttings and cuttings with substrate around the roots (plugs) were transplanted into 3.8-L containers and fertilized with various $P$ fertilizers to determine the effect of fertilizer source on $P$ leaching and plant growth. The following fertilizer treatments were applied: 1) $100 \%$ of the recommended rate of $P$ from controlled-release fertilizer (CRF), consisting of $22 \mathrm{~N}-2.6 \mathrm{P}-10 \mathrm{~K} ; 2) 100 \%$ of $\mathrm{P}$ from triple superphosphate (TSP, $0 \mathrm{~N}-20 \mathrm{P}-0 \mathrm{~K})$ with $\mathrm{N}$ and $\mathrm{K}$ provided by $22 \mathrm{~N}-0 \mathrm{P}-10 \mathrm{~K} \mathrm{CRF}$; and 3 ) $50 \%$ of $\mathrm{P}$ from $\mathrm{CRF}$, consisting of 22N-1.3P-10K, plus 50\% of $P$ from TSP (CRF/TSP). The most $P$ leached from cuttings transplanted as plugs or bareroot and fertilized with TSP, while the least $P$ leached from cuttings transplanted as plugs and fertilized with CRF or CRF/TSP. Plants fertilized with CRF/TSP generally had larger root dry weights than did plants fertilized with CRF or TSP. Plants fertilized with CRF had the smallest stem dry weights. Shoot-to-root (S/R) ratio was largest in plants transplanted as plugs in substrate amended with TSP, but cuttings transplanted bareroot into $\mathrm{CRF}$-amended substrate had the highest $\mathrm{S} / \mathrm{R}$ ratio and the lowest stem $P$ concentration. Incorporation of CRF/TSP into the container substrate can reduce $P$ leaching compared with incorporation of TSP, and can increase root and stem dry weights of plants transplanted as plugs compared with incorporation of CRF.
\end{abstract}

Nutrient-contaminated effluent and its potential pollution of surface and groundwater are of primary concern to the nursery industry. The environmental impact of application of fertilizer, especially $\mathrm{N}$ and $\mathrm{P}$, has been the focus of concern for the past several years. A long-lasting $\mathrm{P}$ source in container crop production is needed because $P$ readily leaches from soilless substrates (Havis and Baker, 1985). The limited nutrient and water retention by soilless substrates necessitates high fertilizer rates and frequent irrigation, contributing to nutrient losses and potential environmental pollution.

Containers limit the amount of substrate and nutrients available to support plant growth. Despite these restrictions, a single application of controlled-release fertilizer (CRF) can adequately supply nutrients through an extended period of the growth cycle (Maynard and

Received for publication 10 Jan. 2000. Accepted for publication 18 May 2000. Approved for publication by the Director, Oklahoma Agricultural Experiment Station. This research was supported under project H-2436. Portions of this paper are from a Master's report submitted by A. Godoy. Plants were provided by Greenleaf Nursery Co. and fertilizers were formulated for this study by IMC Vigoro. The technica assistance of Paula Craig is greatly appreciated. The cost of publishing this paper was defrayed in part by the payment of page charges. Under postal regulations, this paper therefore must be hereby marked advertisement solely to indicate this fact.

${ }^{1}$ Graduate Student.

${ }^{2}$ Professor. E-mail address: jccole@okstate.edu
Lorenz, 1979). Nutrients in soluble fertilizer (SF) are readily available for uptake but are easily leached and can quickly be depleted. Thus growers apply SF several times during the growing season. Controlled-release fertilizer is often more expensive but requires less frequent applications than does SF. Controlledrelease fertilizer is generally coated with plastic polymers or other materials to reduce the speed with which the nutrients become available (Oertli and Lunt, 1962). Therefore, a steady supply of nutrients is provided by CRF over an extended time period, and nutrient leaching is minimized. Many growers have adjusted their fertilizer program to use CRF instead of liquid fertilizers (LF) or SF to decrease the amount of nutrient loss via leaching (Hershey and Paul, 1982). Despite the trend toward use of CRF in production, growers are concerned that growth and development of new transplants, particularly bareroot transplants, may be delayed in substrate amended with CRF because of inadequate nutrient availability from immediately after transplanting until sufficient nutrients have been released into the substrate solution to support growth In contrast, growth of rooted cuttings transplanted as plugs may not be delayed because nutrients are readily available in the plug substrate and may continue to be available until enough nutrients have been released from CRF in the growing substrate to continue to promote plant growth and development

Phosphorus leaches easily when single (SSP) or triple (TSP) superphosphate is used as a fertilizer source (Cole and Dole, 1997;
Dole et al., 1992; Hershey and Paul, 1982; Marconi and Nelson, 1984; Yeager and Barrett, 1984,1986,1988). Cole and Dole (1997) demonstrated that the use of CRF greatly reduces the cumulative amount of $\mathrm{P}$ in leachate in comparison with SF at several temperatures.

Phosphorus readily leaches from pine barkbased substrates because of their low P fixation capacities (Marconi and Nelson, 1984; Yeager and Wright, 1982). Marconi and Nelson (1984) showed that different $P$ fertilizer rates were needed to maintain the same concentration of $\mathrm{P}$ in soil solution in several substrates. Soilless substrates had lower adsorption capacities than did substrates containing soil.

Loss of $\mathrm{P}$ is greater from organic than from mineral soils. Fox and Kamprath (1971) found that $\mathrm{P}$ applied as SF leaches easily from soil primarily composed of organic material $(\mathrm{pH}$ of 4.0) with only traces of inorganic minerals. An average of $95 \%$ of the P applied was lost from organic soil in a leaching column $40 \mathrm{~cm}$ long. Their data agree with those reported for organic soils $(\mathrm{pH}=5)$ by Larsen et al. (1958), who found that $80 \%$ of the $\mathrm{P}$ applied to a 6.7 $\mathrm{cm}$ column of soil was leached with $11.8 \mathrm{~cm}$ of rainfall.

Phosphorus behavior is also influenced by fixation and leaching in a soilless substrate. Yeager and Barrett (1984) found that less P leached from organic substrate consisting primarily of pine bark and peat than from substrate with a lower proportion of organic components. However, the most $\mathrm{P}(76 \%)$ leached from pine bark and peat when sand was added. Cole and Dole (1997) had similar results, with $45 \%$ of the $P$ applied to a 3 pine bark : 1 peat : 1 sand substrate being leached within $13 \mathrm{~d}$. About $80 \%$ of applied P leached from 2 milled pine bark : 1 peat : 1 sand substrate amended with superphosphate within $21 \mathrm{~d}$ (Yeager and Barrett, 1986).

The objectives of this study were to determine the effects of fertilizer source on: 1) the quantities of $\mathrm{P}$ leaching from a container substrate, and 2) plant growth and tissue $\mathrm{P}$ concentration of cuttings transplanted bareroot or as plugs.

\section{Materials and Methods}

Thirty uniform, commercially propagated, bareroot cuttings and 30 similarly propagated cuttings with growing substrate around the roots (plugs) of 'Halward's Silver' spirea were planted on 15 Feb. 1997 in 16-cm-diameter $\times$ 17.5-cm-deep (3.8-L) pots containing $1200 \mathrm{~g}$ (bareroot) or $1100 \mathrm{~g}$ (plugs) of a 3 pine bark : 1 peat : 1 sand (by volume) substrate amended with $0.9 \mathrm{~kg} \cdot \mathrm{m}^{-3}$ Micromax (The Scotts Co., Marysville, Ohio), $2.3 \mathrm{~kg} \cdot \mathrm{m}^{-3}$ each of dolomite and gypsum, and the following macronutrient fertilizer treatments: 1) $100 \%$ of $\mathrm{P}$ applied as $8.1 \mathrm{~kg} \cdot \mathrm{m}^{-3}$ of $22 \mathrm{~N}-2.6 \mathrm{P}-10 \mathrm{~K}$ CRF (IMC Vigoro, Winter Haven, Fla.); 2) $100 \%$ of $\mathrm{P}$ applied in $1.0 \mathrm{~kg} \cdot \mathrm{m}^{-3}$ triple superphosphate (TSP, 0N-20P-0K,) with $\mathrm{N}$ and $\mathrm{K}$ applied as $8.1 \mathrm{~kg} \cdot \mathrm{m}^{-3}$ of $22 \mathrm{~N}-0 \mathrm{P}-10 \mathrm{~K} \mathrm{CRF}$; and 3$) 50 \%$ of $\mathrm{P}$ applied as $8.1 \mathrm{~kg} \cdot \mathrm{m}^{-3}$ of $22 \mathrm{~N}-1.3 \mathrm{P}-10 \mathrm{~K}$ CRF plus $50 \%$ of $\mathrm{P}$ applied as $0.5 \mathrm{~kg} \cdot \mathrm{m}^{-3} \mathrm{TSP}$ (CRF/TSP). Fertilizers were applied to all 
treatments to provide equal amounts of $\mathrm{N}$ ( 1.8 $\left.\mathrm{kg} \cdot \mathrm{m}^{-3}\right)$ and $\mathrm{K}\left(0.7 \mathrm{~kg} \cdot \mathrm{m}^{-3}\right)$ from the same source, and equal amounts of $\mathrm{P}\left(90 \mathrm{~g} \cdot \mathrm{m}^{-3}\right)$ but from different sources.

The growing substrate adhering to the roots of the plugs consisted of 5 pine bark : 1 perlite : 1 peat (by volume) amended with 4.1 $\mathrm{kg} \cdot \mathrm{m}^{-3}$ of dolomite, $1.2 \mathrm{~kg} \cdot \mathrm{m}^{-3}$ gypsum, and $0.2 \mathrm{~kg} \cdot \mathrm{m}^{-3}$ of TSP. The substrate adhering to the roots added $\approx 100 \mathrm{~g}$ to the final mix ( 3 pine bark : 1 peat : 1 sand) to make the amount of substrate $(1200 \mathrm{~g})$ in the containers with plugs equal to that of the bareroot cuttings.

The final growing substrate had 50\% total porosity (liquid and air), 20\% air space, $30 \%$ total water holding capacity, and a bulk density of $0.4 \mathrm{~g} \cdot \mathrm{mL}^{-1}$, as measured using procedures described by Ingram et al. (1990). Plants were grown in a polyethylene-covered greenhouse with an average air temperature of $29{ }^{\circ} \mathrm{C}$ day $/ 18^{\circ} \mathrm{C}$ night, and a maximum photosynthetic photon flux $(P P F)$ of 924 $\mu \mathrm{mol} \cdot \mathrm{m}^{-2} \cdot \mathrm{s}^{-1}$.

About $12 \mathrm{~h}$ prior to planting, $500 \mathrm{~mL}$ tap water was surface-applied to the substrate in each pot to assure that adequate moisture was present to sustain the plants. Immediately after transplanting, $250 \mathrm{~mL}$ of tap water was applied to the substrate surface. Thereafter, plants were irrigated when a predetermined test plant was at or below $50 \%$ available water as indicated by weight. To determine the target weight, five plants other than those used in the study described above were planted in $1200 \mathrm{~g}$ of the same container substrate as the experimental plants. These plants were watered to container capacity and plant, pot, and substrate weights were recorded. Plants were allowed to dry to the permanent wilting point, and plant, pot, and substrate weights were again recorded. Target irrigation weights were calculated as follows: [(container capacity weight - wilting point weight) $(0.50)$ ] + wilting point weight $=$ the total plant weight at $50 \%$ available water. Target weight was obtained by averaging the five container weights. When the weight of test plants reached the target weight or below, all plants were irrigated by applying a predetermined volume of tap water to the substrate surface with a graduated cylinder to achieve $\approx 25 \%$ leaching fraction. Three samples of the tap water were collected to determine the amount of $\mathrm{P}$ applied with the water at each irrigation.

The volumes of water applied and of leachate per pot were recorded at each irrigation. Plastic funnels were used to direct all leachate into plastic sample bottles, and leachate volume was measured with a graduated cylinder. Leaching fraction was calculated as: volume of leachate/volume of water applied. Leachate samples were collected at each irrigation and stored at $7{ }^{\circ} \mathrm{C}$ until analyzed for $\mathrm{pH}(\mathrm{pH} / \mathrm{mV} / \mathrm{Temp}$ Bench Meter; Cole-Parmer Instruments, Chicago), electrical conductivity (EC) (Solubridge, Beckman Instruments, Cedar Grove, N.J.), and total P concentration by the hydroquinone method (Page et al., 1982) using a recording spectrophotometer at $700 \mathrm{~nm}$ (model UV-1601; Shimadzu Corp., Kyoto, Japan).
The plants were harvested on 6 June 1997 after 26 irrigations. Plant height and plant diameter (average of diameter at widest point and the diameter perpendicular to the widest point) were determined at harvest. Plants from each treatment were divided into roots, stems, and leaves, and the tissues were dried at $70{ }^{\circ} \mathrm{C}$ for $7 \mathrm{~d}$, weighed, and ground to pass through a $917-\mu \mathrm{m}$ mesh screen. Then $1 \mathrm{~g}$ of each sample was dry-ashed, and $\mathrm{P}$ was determined colorimetrically (Olsen and Summers, 1982). Shoot : root $(S / R)$ ratio was calculated as [(stem dry weight + leaf dry weight)/root dry weight].

Statistical analysis. This experiment was a two by three factorial in a randomized complete-block design with 10 replications. The factorial treatments were the two cutting types (bareroot and plugs) and the three $\mathrm{P}$ fertilizer treatments. Data were analyzed using the general linear model procedure with mean separations by LSD or StudentNewman-Keul's procedures when appropriate (SAS Institute, Cary, N.C.). Regression models for leachate volume and amount of $P$ leached were fit using Tablecurve ${ }^{\mathrm{TM}}$ 2D (Jandel Scientific, San Rafael, Calif.).

\section{Results}

Cutting treatment interacted with fertilizer treatment for leaching fraction (Table 1). Cuttings transplanted as plugs into substrate containing CRF had a larger leaching fraction $(31 \%)$ than did plugs with substrate containing CRF/TSP $(26 \%)$ or TSP $(27 \%)$. In contrast, greater leaching fractions occurred with bareroot transplants in substrate containing CRF $(27 \%)$ and CRF/TSP $(27 \%)$ than in substrate containing TSP $(23 \%)$.

No cutting $\times$ fertilizer interaction occurred for the amount of $\mathrm{P}$ leached (Table 1). More $\mathrm{P}$ leached from bareroot cuttings than from plugs given the same fertilizer treatment. About twice as much $\mathrm{P}$ leached from plugs or bareroot cuttings receiving TSP as from those in substrate with CRF or CRF/TSP. The P leaching patterns over the course of the study differed depending on fertilizer source (Fig. 1). A large proportion of $P$ leached in a

Table 1. Effects of spirea cutting treatment and source of $\mathrm{P}$ on leaching fraction, $\mathrm{P}$ leached, and initial and final leachate $\mathrm{pH}$ and electrical conductivity (EC), $\mathrm{n}=10$.

\begin{tabular}{|c|c|c|c|c|c|c|c|}
\hline \multirow{2}{*}{$\begin{array}{l}\text { Cutting } \\
\text { treatment }\end{array}$} & \multirow[b]{2}{*}{ Fertilizer } & \multirow{2}{*}{$\begin{array}{l}\text { Leaching } \\
\text { fraction }(\%)\end{array}$} & \multirow{2}{*}{$\begin{array}{c}\text { Total P } \\
\text { leached }(\mathrm{mg})\end{array}$} & \multicolumn{2}{|c|}{$\mathrm{pH}$} & \multicolumn{2}{|c|}{$\mathrm{EC}\left(\mathrm{dS} \cdot \mathrm{m}^{-1}\right)$} \\
\hline & & & & Initial & Final & Initial & Final \\
\hline \multirow[t]{4}{*}{ Plugs } & $\mathrm{CRF}^{\mathrm{z}}$ & $31 \mathrm{a}^{\mathrm{y}}$ & 34.5 & 6.07 & $6.66 \mathrm{ab}$ & $2.68 \mathrm{bc}$ & 1.95 \\
\hline & CRF/TSP & $26 \mathrm{~b}$ & 32.4 & 5.39 & $6.66 \mathrm{ab}$ & $3.05 \mathrm{ab}$ & 1.97 \\
\hline & TSP & $27 \mathrm{~b}$ & 75.2 & 5.18 & $6.73 \mathrm{a}$ & $2.87 \mathrm{abc}$ & 1.99 \\
\hline & Mean & 28 & $47.3 \mathrm{~b}$ & 5.55 & 6.67 & 2.90 & 1.98 \\
\hline \multirow[t]{4}{*}{ Bareroot cuttings } & CRF & $27 \mathrm{~b}$ & 46.4 & 6.09 & $6.56 \mathrm{ab}$ & $2.97 \mathrm{abc}$ & 1.83 \\
\hline & CRF/TSP & $27 \mathrm{~b}$ & 40.4 & 5.46 & $6.93 \mathrm{a}$ & $2.59 \mathrm{c}$ & 1.82 \\
\hline & TSP & $23 \mathrm{c}$ & 87.7 & 4.86 & $6.25 \mathrm{~b}$ & $3.13 \mathrm{a}$ & 1.96 \\
\hline & Mean & 26 & $58.1 \mathrm{a}$ & 5.47 & 6.58 & 2.86 & 1.87 \\
\hline \multirow[t]{4}{*}{ Mean } & CRF & 29 & $40.4 \mathrm{~B}$ & $6.07 \mathrm{~A}$ & 6.59 & 2.99 & 1.94 \\
\hline & CRF/TSP & 26 & $36.4 \mathrm{~B}$ & $5.42 \mathrm{~B}$ & 6.80 & 2.82 & 1.87 \\
\hline & TSP & 25 & $81.4 \mathrm{~A}$ & $5.02 \mathrm{C}$ & 6.49 & 2.82 & 1.97 \\
\hline & Interaction & $* *$ & NS & NS & $*$ & $*$ & NS \\
\hline
\end{tabular}

${ }^{2} \mathrm{CRF}=100 \%$ of $\mathrm{P}$ from controlled-release fertilizer, $\mathrm{CRF} / \mathrm{TSP}=50 \%$ of $\mathrm{P}$ from $\mathrm{CRF}$ and $50 \%$ from triple superphosphate (TSP), TSP $=100 \%$ of P from TSP.

${ }^{\mathrm{y}}$ Mean separation among means within columns by LSD, $P \leq 0.05$ (a, b, c) or $\leq 0.001$ (A, B, C).

NS,*,**Nonsignificant or significant at $P \leq 0.05$ or 0.01 , respectively. relatively small volume of leachate $(<875$ ) with TSP. In contrast, the amount of $P$ throughout the study. With CRF there appeared to be a lag phase in which little $\mathrm{P}$ leached initially, but more $\mathrm{P}$ leached after $\approx 875 \mathrm{~mL}$ leachate was collected.

Cutting treatment $\times$ fertilizer interaction was nonsignificant for initial leachate $\mathrm{pH}$, but asignificant difference occurred among fertilCRF-amended substrate had the highest initial $\mathrm{pH}$. Transplant by fertilizer interaction was significant for final leachate $\mathrm{pH}$. With plugs, the final leachate $\mathrm{pH}$ did not differ among the ings with TSP-amended substrate than with substrate amended with CRF/TSP (6.93).

Cutting treatment interacted with fertilizer in affecting initial leachate EC (Table 1). With plugs, initial leachate EC did not significantly differ among fertilizer treatments, (3.13 (3.13 $\left.\mathrm{dS} \cdot \mathrm{m}^{-1}\right)$ with TSP-amended substrate (2.59 dS. $\left.\mathrm{m}^{-1}\right)$ with CRF/TSP not affected by treatment.

Cutting treatment $\times$ fertilizer interaction was nonsignificant for $\mathrm{P}$ concentration in roots, stems and leaves (Table 2). Cuttings the the leaves and stems was not affected. Fertilizer treatments did not affect total $\mathrm{P}$ concentration in roots or leaves. The plants receiving CRF had lower P concentrations in stems than did plants receiving TSP, and those concentration. weightatharvest. Plants transplanted as plugs were taller $(82.3 \mathrm{~cm})$ and had greater leaf dry weights $(10.1 \mathrm{~g})$ at harvest than did plants transplanted bareroot $(65.9 \mathrm{~cm}$ and $8.7 \mathrm{~g})$. Height and leaf dry weight were not affected by fertilizer treatment (data not shown). Plant width was not affected by cutting treatment thation in roots than did those transplanted receiving CRF/TSP were intermediate in stem 

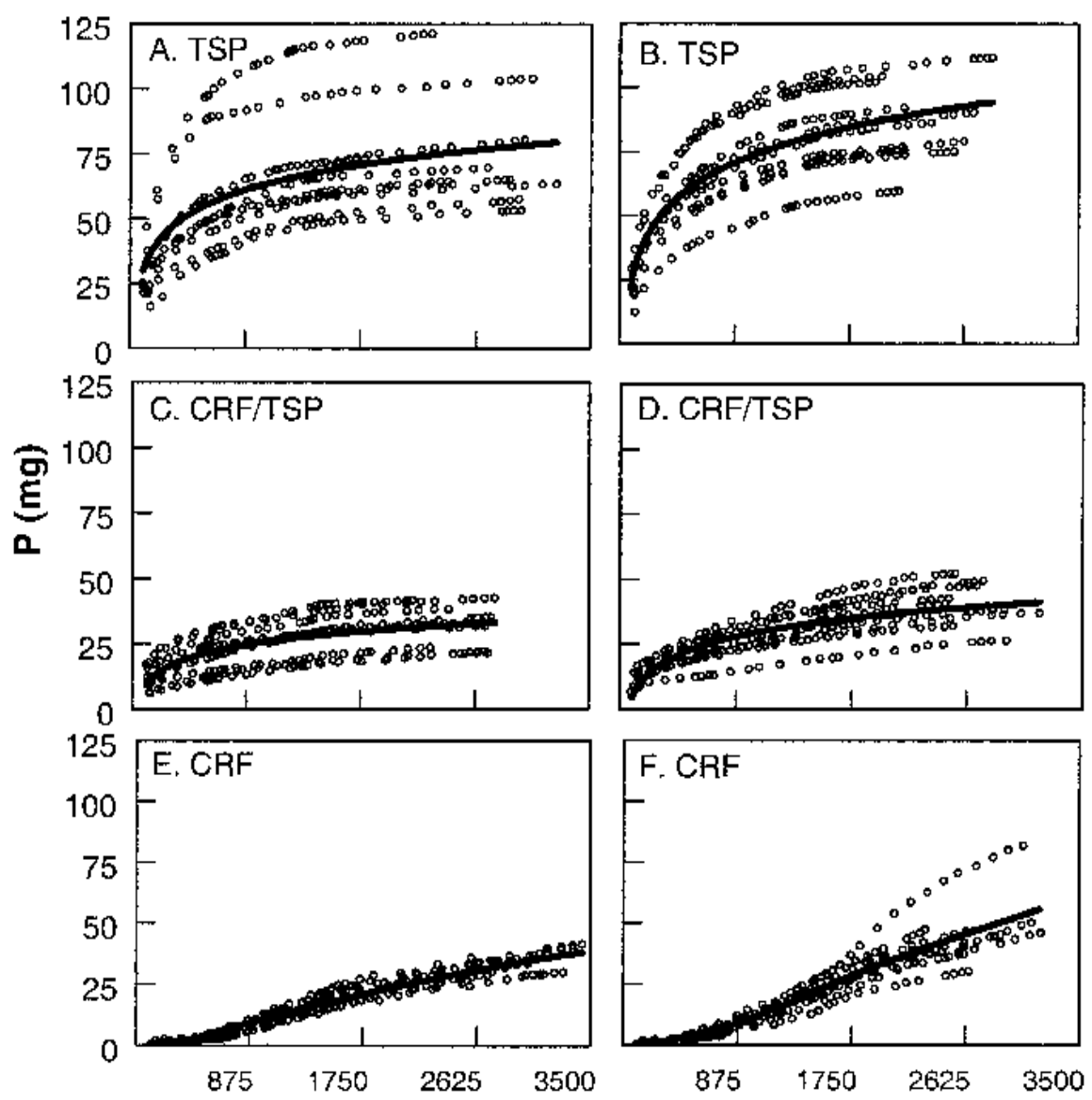

\section{Volume of leachate $(\mathrm{mL})$}

Fig. 1. Amount of $\mathrm{P}$ in leachate from substrate amended with $\mathrm{P}$ from triple superphosphate (TSP), 50\% controlled-release fertilizer (CRF), and 50\% TSP or CRF and with cuttings transplanted as (A, C, E) plugs or $(\mathbf{B}, \mathbf{D}, \mathbf{F})$ bareroot. The regression equations were as follows: $100 \% \mathrm{SF}: \mathrm{y}=\mathrm{a}+\mathrm{b} / \mathrm{lnx}$, cuttings with substrate $\mathrm{a}=149.20$ and $\mathrm{b}=-586.59\left(r^{2}=0.26\right)$, bareroot cuttings $\mathrm{a}=189.37$ and $\mathrm{b}=-788.19$ $\left(r^{2}=0.56\right) ; 50 \%$ CRF: $\mathrm{y}=\mathrm{a}+\mathrm{b}(\operatorname{lnx})^{2}$, cuttings with substrate $\mathrm{a}=-5.74$ and $\mathrm{b}=0.69\left(r^{2}=0.50\right)$, bareroot cuttings $\mathrm{a}=-8.80$ and $\mathrm{b}=0.79\left(r^{2}=0.62\right) ; 100 \%$ CRF: lny $=\mathrm{a}+\mathrm{b} / \mathrm{x}^{0.5}$, cuttings with substrate $\mathrm{a}=5.06$ and $\mathrm{b}=-82.67\left(r^{2}=0.95\right)$; bareroot cuttings $\mathrm{a}=5.71$ and $\mathrm{b}=-100.66\left(r^{2}=0.78\right)$.

or fertilizer source (data not shown). Cutting treatment interacted with fertilizer treatment in affecting root and stem dry weight and $\mathrm{S} / \mathrm{R}$ ratio (Table 3 ). Root dry weights were largest in CRF/TSP regardless of cutting type. Plants transplanted as plugs had the smallest root dry weight with TSP while those transplanted as bareroot cuttings had the smallest root dry weight with CRF. Shoot dry weights of plants transplanted as plugs were largest with $\mathrm{CRF} / \mathrm{TSP}$ and smallest with $\mathrm{CRF}$, whereas shoot dry weights of plants transplanted as bareroot cuttings did not differ among fertilizer treatments. Shoot : root ratio of plants transplanted as plugs was largest with TSP and smallest with CRF. In contrast, $\mathrm{S} / \mathrm{R}$ ratio of plants transplanted as bareroot cuttings was largest with CRF and smallest with CRF/TSP.

\section{Discussion}

Controlled-release fertilizers are manufactured to release nutrients over several months to provide plants with a relatively steady supply of nutrients throughout the production cycle. In contrast, SF are immediately and completely soluble; therefore, nutrients are more prone to leaching from the growth substrate with SF than with CRF. The results of this study agree with those of Cole and Dole (1997), Marconi and Nelson (1984), and Yeager and Barrett $(1984,1986)$ in that SF were easily leached from the soilless substrate, apparently because of a low adsorption capacity of organic and inorganic media components. In contrast, nutrient release from CRF into the substrate solution was restricted by the fertilizer formulation.

Transplant treatment affected leachate $\mathrm{P}$ content in this study (Table 1 ). The cuttings transplanted as plugs had a substrate consisting of 5 pine bark: 1 perlite : 1 peat around the roots at transplanting while the bareroot cuttings did not. The lower P content of leachate from plants transplanted as plugs than from those transplanted bareroot may be partially explained by less leaching from the slightly higher proportions of bark and perlite in the original plug growing substrate than in the final growing substrate. In contrast, the slightly higher proportion of sand in the final
Table 2. Effects of spirea cutting treatment and $\mathrm{P}$ source on $\mathrm{P}$ concentration in roots, stems, and leaves, $\mathrm{n}=10$.

\begin{tabular}{|c|c|c|c|}
\hline \multirow[b]{2}{*}{ Treatments } & \multicolumn{3}{|c|}{ Total P (\%) } \\
\hline & Roots & Stems & Leaves \\
\hline \multicolumn{4}{|c|}{ Main effects of cutting treatment $(C)$} \\
\hline Plugs & $0.46 b^{z}$ & 0.41 & 0.37 \\
\hline \multirow[t]{2}{*}{ Bareroot cuttings } & $0.51 \mathrm{a}$ & 0.42 & 0.37 \\
\hline & & NS & NS \\
\hline \multicolumn{4}{|c|}{ Main effects of fertilizer $(F)$} \\
\hline $\mathrm{CRF}^{\mathrm{y}}$ & 0.47 & $0.37 \mathrm{~b}$ & 0.35 \\
\hline CRF/TSP & 0.49 & $0.41 \mathrm{ab}$ & 0.37 \\
\hline TSP & 0.50 & $0.46 \mathrm{a}$ & 0.39 \\
\hline & NS & & NS \\
\hline $\mathrm{C} \times \mathrm{F}$ & NS & NS & NS \\
\hline
\end{tabular}

${ }^{\mathrm{z}}$ Mean separation within columns and main effects by Student-Newman-Keul's Procedure $P<0.05$. ${ }^{y} \mathrm{CRF}=100 \%$ of $\mathrm{P}$ from controlled release fertilizer, $\mathrm{CRF} / \mathrm{TSP}=50 \%$ of $\mathrm{P}$ from $\mathrm{CRF}$ and $50 \%$ from triple superphosphate (TSP), TSP $=100 \%$ of $\mathrm{P}$ from TSP.

${ }^{\text {NS}}$ Nonsignificant.

Table 3. Effects of spirea cutting treatment and source of $\mathrm{P}$ on root and stem dry weight and shoot : root $(\mathrm{S} / \mathrm{R})$ ratio at harvest. $\mathrm{n}=10$.

\begin{tabular}{lcccc}
\hline \hline Cutting & & \multicolumn{2}{c}{ Dry wt $(\mathrm{g})$} & \\
\cline { 3 - 4 } treatment & Fertilizer & Root & Stem & ratio \\
\hline Plugs & CRF $^{z}$ & $3.9 \mathrm{~b}^{\mathrm{y}}$ & $7.3 \mathrm{~d}$ & $4.3 \mathrm{c}$ \\
& CRF/TSP & $4.3 \mathrm{a}$ & $9.4 \mathrm{a}$ & $4.7 \mathrm{~b}$ \\
& $\mathrm{TSP}$ & $3.4 \mathrm{c}$ & $9.0 \mathrm{ab}$ & $5.7 \mathrm{a}$ \\
Bareroot & & & & \\
cuttings & $\mathrm{CRF}$ & $3.9 \mathrm{~b}$ & $7.5 \mathrm{~cd}$ & $4.3 \mathrm{c}$ \\
& $\mathrm{CRF} / \mathrm{TSP}$ & $4.4 \mathrm{a}$ & $7.6 \mathrm{~cd}$ & $3.8 \mathrm{e}$ \\
& $\mathrm{TSP}$ & $4.2 \mathrm{ab}$ & $8.3 \mathrm{bc}$ & $4.1 \mathrm{~d}$ \\
Interaction & & $*$ & $*$ & $* * *$
\end{tabular}

${ }^{2} \mathrm{CRF}=100 \%$ of $\mathrm{P}$ from controlled release fertilizer, CRF/TSP $=50 \%$ of $\mathrm{P}$ from CRF and $50 \%$ from triple superphosphate (TSP), TSP $=100 \%$ of $\mathrm{P}$ from TSP.

${ }^{\mathrm{y}}$ Mean separation within columns by LSD, $P \leq 0.05$.

***** Significant at $P \leq 0.05$ or 0.001 , respectively.

growing medium may have increased $\mathrm{P}$ leaching somewhat from the cuttings transplanted bareroot. Yeager and Barrett (1984, 1986) showed that $\mathrm{P}$ easily leached from media containing pine bark, peat, and sand, whereas omission of the sand reduced $\mathrm{P}$ concentration in the leachate.

The results of this study are similar to others in which minimal effects of fertilizer type on plant growth were observed (Dole and Cole, 1997; Dole et al., 1992; Morvant, 1995). The larger root dry weights of plants in substrate containing CRF/TSP than in the other fertilizer treatments can be attributed to the greater availability of $\mathrm{P}$ in the substrate solution with TSP, combined with the presence of P in the substrate solution throughout the production cycle with CRF. Plants receiving CRF/TSP had greater root dry weights regardless of transplant method, and greater stem dry weights when transplanted bareroot than did similar plants receiving other fertilizer treatments (Table 3). Less $\mathrm{P}$ was leached from CRF/TSP than from other fertilizer treatments, suggesting that combining CRF with SF may lead to better plant growth while reducing nutrient leaching. 
Results of this study indicate that incorporation of CRF/TSP into container plant growing substrate is a good compromise between incorporation of CRF or of TSP. The CRF/ TSP generally increased root and shoot dry weights more than did CRF while reducing $\mathrm{P}$ leaching during the production cycle more than did SF.

\section{Literature Cited}

Cole, J.C. and J.M. Dole. 1997. Temperature and phosphorus source affect phosphorus retention by a pine bark-based container medium. HortScience 32:236-240.

Dole, J.M., J.C. Cole, and R.M. Smith. 1992. Effect of controlled-release and constant liquid fertilization on leachate and plant quality. HortScience 27:582. (Abstr.)

Fox, R.L. and E.J. Kamprath. 1971. Adsorption and leaching of $\mathrm{P}$ in acid organic soils and high organic matter sand. Proc. Soil Sci. Soc. Amer. 35:154-156.

Havis, J.R. and J.H. Baker. 1985. Influence of liming rate on phosphorus leaching from a peat- sand medium. J. Environ. Hort. 3:74-76.

Hershey, D.R. and J.L. Paul. 1982. Leaching-losses of nitrogen from pot chrysanthemums with controlled-release and liquid fertilization. Scientia Hort. 17:145-152.

Ingram, D.L., R.W. Henley, and T.H. Yeager. 1990. Diagnostic and monitoring procedures for nursery crops. Univ. of Florida. Coop. Ext. Serv. Circ. 556.

Larsen, J.E., R. Langston, and G.F. Warren. 1958. Studies on the leaching of applied labeled phosphorus in organic soils. Soil Sci. Soc. Amer. Proc. 22:558-560.

Marconi, D.J. and P.V. Nelson. 1984. Leaching of applied phosphorus in container media. Scientia Hort. 22:275-285.

Maynard, D.N. and O.A. Lorenz. 1979. Controlled release fertilizers for horticultural crops. Hort. Rev. 1:79-91.

Morvant, J.K. 1995. Effects of irrigation method on plant growth, water, and nutrient efficiency, and run-off. MS Thesis, Dept. of Horticulture and Landscape Architecture, Oklahoma State Univ., Stillwater.

Oertli, J.J. and O.R. Lunt. 1962. Controlled release of fertilizer minerals by incapsulating mem- branes: I. Factors influencing the rate of release. Soil Sci. Soc. Proc. 26:579-583.

Olsen, S.R. and L.E. Sommers. 1982. Phosphorus, p. 404-430. In: A.L. Page, R.H. Miller, and D.R. Keeney (eds.). Methods of soil analysis. Part 2. Chemical and microbiological properties. Amer. Soc. Agron. and Soil Sci. Soc. Amer., Madison, Wis.

Page, A.L., R.H. Miller, and P.R. Keeney. 1982. Methods of soil analysis. Part 2. Chemical and microbial properties. Amer. Soc. Agron. and Soil Sci. Amer., Madison, Wis.

Yeager, T.H. and J.E. Barrett. 1984. Phosphorus leaching from ${ }^{32} \mathrm{P}$ superphosphate amended soilless container media. HortScience 19:216217.

Yeager, T.H. and J.E. Barrett. 1986. Influence of an aluminum amendment on phosphorus leaching from a container medium. HortScience 21:262263.

Yeager, T.H. and J.E. Barrett. 1988. Phosphorus in superphosphate amended soilless media. Fla. Ornamental Growers Assn. Nwsl. 11(6):1-2.

Yeager, T.H. and R.D. Wright. 1982. Pine barkphosphorus relationships. Commun. in Soil Sci. Plant Anal. 13:57-66. 